\title{
Phylogenetic analysis of influenza A(H1N1)pdm viruses isolated in Ukraine during the 2009-2010 pandemic season
}

\author{
L. V. Leibenko ${ }^{1,2}$, V. P. Polischuk ${ }^{1}$, A. P. Mironenko² \\ ${ }^{1}$ ESC «Institute of Biology», Taras Shevchenko National University of Kyiv \\ 64/13, Volodymyrska Str., Kyiv, Ukraine, 01601 \\ ${ }^{2}$ Gromashevsky L.V. Institute of epidemiology and infection diseases, NAMS of Ukraine \\ 5, Amosova Str., Kyiv, Ukraine, 03038 \\ leiblu@mail.ru
}

\begin{abstract}
Aim. To perform the phylogenetic analysis of segments, encoding hemagglutinin and neuraminidase of A(H1N1) pdm influenza viruses, isolated in Ukraine. Methods. In this study the real-time polymerase chain reaction (RT-PCR), sequencing and phylogenetic analysis methods were used. Results. Key mutations in amino acid sequences of proteins of Ukrainian pandemic influenza isolates were analyzed. High genetic similarity of Ukrainian and foreign pandemic isolates (99\%) was observed. Conclusions. The stability of Ukrainian isolates genes during 2009-2010 pandemic season was shown.
\end{abstract}

Keywords: phylogenetic analysis, nucleotide sequence, A(H1N1)pdm influenza viruses.

Introduction. Widespread outbreak of swine influenza that took place in 2009 came unexpected by a scientific community, the forecasts of which were centered on the possibility of avian influenza pandemic caused primarily by $\mathrm{A} / \mathrm{H} 5 \mathrm{~N} 1$ and $\mathrm{A} / \mathrm{H} 9 \mathrm{~N} 2$ viruses [1-3]. A triple reassortant virus containing genes from swine, avian and human influenza viruses was absolutely new for a human immune system, which led to disease complications and high mortality [4]. During the 2009-2010 season 1128 people died from influenza complications only just in Ukraine. According to the WHO data 4879 people died from influenza in 53 European countries during the same period [5].

Classical type A swine influenza virus can sporadically infect humans being transmitted from sick animals. The ability of such viruses to transmit between humans is limited. However, it is suggested that swine may serve as a mixing vessel' to create new reassortants using genes of swine, avian and human influenza

(C) Institute of Molecular Biology and Genetics, NAS of Ukraine, 2013 viruses [6]. Such mixing is possible due to the presence of two types of receptors (2'-3' and 2'-6' residuals of sialic acid) in the respiratory tract of swine. These receptors are located on the host cell surface and used by influenza viruses to enter sensitive cells. It is thought that a new influenza virus, $\mathrm{A}(\mathrm{H} 1 \mathrm{~N} 1) \mathrm{pdm}$, which caused the 2009 pandemic has arisen due to a gene recombination (genetic shift) [7, 8].

Genetic analysis helped to reveal that some RNA segments of $A(H 1 N 1) p d m$ influenza virus originated from viruses affecting different hosts. The study of genetic changes is very important as evidenced, for example, by a retrospective identification of nucleotide sequence of «Spanish» $\mathrm{A}(\mathrm{H} 1 \mathrm{~N} 1)$ influenza virus - the pathogen which caused the 1918 flu pandemic [9], and intensive use of these sequences in the study of viruses circulating at present. A phylogenetic analysis applied to new influenza isolates allows monitoring the rate and direction of virus variations practically in real time. Moreover, a comparative analysis of their protein sequences allows revealing the point amino acid replace- 
ments providing the mechanism of virus adaptation to the human immune system. Sequences of surface antigens - hemagglutinin (HA) and neuraminidase (NA) are usually used for genetic analyses. A comparative phylogenetic analysis of HA and NA sequences of A(H1N1) pdm influenza viruses circulated in Ukraine during the pandemic 2009-2010 season was the aim of the study.

Materials and methods. Nasal-throat wash outs and biopsy material taken from influenza-affected individuals in different regions of Ukraine during pandemic outbreak were used in the study. In total, 466 samples were analyzed by real-time polymerase chain reaction (RT-PCR) using the AgPath-IDTM One-Step RT-PCR Kit («Ambion», USA) and the AB 7500 Real Time PCR System for the in vitro qualitative detection of influenza viral RNA. For RNA extraction the Instant Virus RNA Kit («Analytik Jena», Germany) was used. We used panel of primers and dual-labeled hydrolysis (Taq Man) probes to InfA, SW InfA, SW H1 and RnaseP, sent us by the Centers for Disease Control and Prevention (CDC, USA). For PCR detection we used CDC protocol of real-time RT-PCR for swine influenza A(H1N1). $H A$ and $N A$ gene sequences of pandemic isolates $\mathrm{A} /$ Ternopil/N11/ 2009, A/Ternopil/N10/2009, A/Lviv/N2/ 2009, A/Lviv/N6/2009 and A/Kyiv/N1/2009 were selected to perform phylogenetic comparisons. Phylogenetic analysis was performed using MEGA 5 software [10].

Sequences of pandemic influenza viruses from other countries were received from Genbank (http://www.ncbi. nlm.nih.gov/Genbank) and GISAID resource (http:// platform.gisaid.org/), using BLAST (Basic Local Alignment Search Tool) analysis (http://www.ncbi.nlm.nih. gov/Blast.cgi). Sequences were aligned using ClustalW algorithm with default gap parameters and the «IUB» DNA weight matrix. Phylogenetic trees were built by the neighbor joining method (NJ) [11] applying Kimura 2-parameter model [12]. Evolutional distances were calculated in terms of the number of base substitutions per site. A bootstrap technique with 1000 replications was used to test statistical validity of received data [13]. Nucleotide sequences were translated into amino acid sequences using EMBOSS Transeq translates (http:// www.ebi.ac.uk/Tools/st/emboss_transeq/).

Results and discussion. In this study we compared nucleotide sequences encoding surface antigens of in- fluenza viruses - HA and NA proteins - because they are highly prone to mutation-related changes. High (99\%) similarity of $H A$ and NA genes was observed for viruses isolated on different continents already at the stage of BLAST system-assisted search and was confirmed by the data obtained by other authors $[14,15]$. Taking into account a considerable number (exceeding 1000) of available sequences of pandemic influenza viruses, the geographic location and date when the material was sampled from a sick person were chosen as main criteria for search and selection.

In view of the fact that HA of pandemic influenza viruses originated from swine influenza viruses [15], we selected the sequences of viruses with relatively high similarity to pandemic ones: A/Ohio/01/2007 isolate being $93 \%$ similar; swine influenza viruses $-\mathrm{A} / \mathrm{swine} /$ Illinois/1/1975 and A/swine/Ohio/23/1935 having 87 and $83 \%$ similarity, respectively. We also selected the sequence of a classical reference strain of human influenza virus (H1N1) - A/New Caledonia/20/1999 possessing $67 \%$ similarity. The Results of phylogenetic analysis are presented in the form of phylogenetic trees (dendrograms) and given in Fig. 1-4.

Comparison of hemagglutinin (HA) genes. While comparing $H A$ gene segments it was found that the triple reassortant A/Ohio/01/2007 influenza virus (Fig. 1) isolated from a person suffered from swine influenza is the most similar to the pandemic isolates [7]. HA found in Ohio virus originated from swine influenza viruses in North American region [7, 16]. Influenza viruses isolated from pigs in USA in 1935 and 1975 turned out to be the most dissimilar. The reference strain of seasonal human influenza virus, A/NewCaledonia/20/1999, showed the smallest similarity (Fig. 1) confirming the data obtained by different authors $[7,15,16]$ with respect to the origin of HA of pandemic $\mathrm{A}(\mathrm{H} 1 \mathrm{~N} 1) \mathrm{pdm}$ influenza viruses from swine influenza viruses in North American region around 1930s.

All Ukrainian isolates of the 2009-2010 season selected for the analysis were located among pandemic influenza viruses isolated in other countries (Fig. 1). The high homogeneity of A(H1N1)pdm influenza virus population did not allow accurate observation of the pattern of phylogenetic relations within the population itself. That is why a phylogenetic study analyzing only sequences of pandemic influenza viruses of the 2009- 


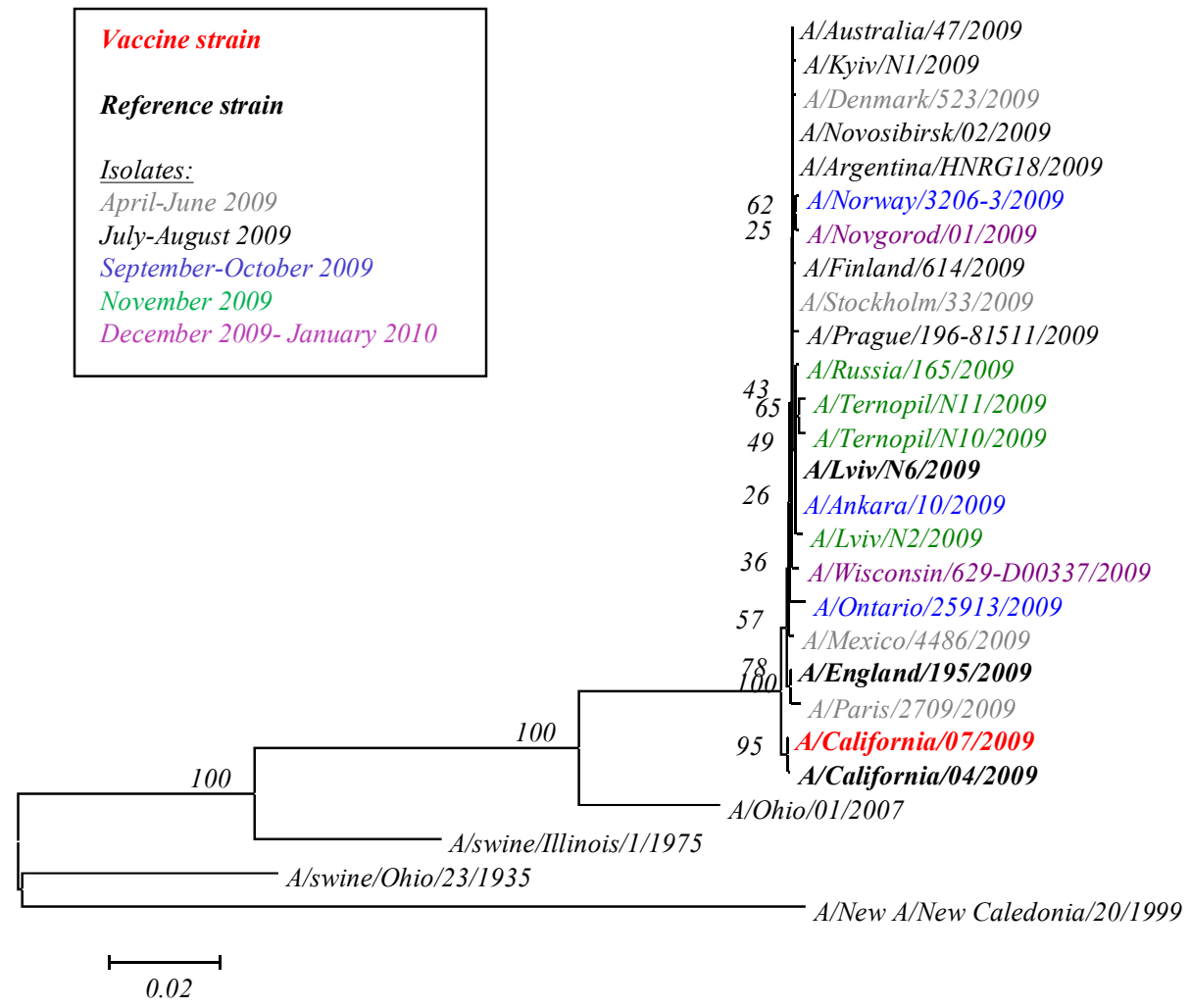

Fig. 1. Molecular phylogenetic analysis of HA nucleotide sequences from pandemic and seasonal A type influenza viruses (H1N1)
2010 season was performed. The results of the analyses are presented in Fig. 2 in the form of a rootless phylogenetic tree. By differences in HA genes the analyzed viruses were allocated into four clusters.

Ukrainian isolates were located within two clusters: A/Kyiv/N1/2009 was found in the first cluster, together with viruses from Europe, USA and Australia, while A/Lviv/N2/2009, A/Lviv/N6/2009, A/Ternopil/ $\mathrm{N} 10 / 2009$ and $\mathrm{A} / \mathrm{Ternopil/N11/2009}$ viruses were allocated to the second cluster together with viruses isolated in Russia and Turkey. A(H1N1)pdm isolates are marked by a color corresponding to the place of isolation (Fig. 1, 2). The fact that Ukrainian isolates were found in different clusters allows the suggestion that autumn Lviv and Ternopil isolates do not originate from a summer $\mathrm{A} / \mathrm{Kyiv} / \mathrm{N} 1 / 2009$ isolate, but were brought to Ukraine later. In addition, one may assume that, at least, two genetically different groups of pandemic influenza viruses (H1N1) circulating within the borders of our country were brought by different ways.

While comparing viruses allocated to different clusters it was found that the first cluster was composed of specimens isolated from influenza-affected patients during a prolonged period of time - starting from the first occurrences of pandemic influenza in April 2009 until the fading of its second wave in January 2010. Viruses allocated to the first cluster demonstrated stable genetic sequences and, respectively, stable antigenic properties of the pathogen. The second and third clusters comprising the majority of Ukrainian isolates included viruses isolated during autumn and winter in 20092010. They formed the group of A/Lviv/N6/2009 - like viruses, the Ukrainian isolate being selected as a reference strain. The fourth cluster draws attention by the fact that it contains only viruses isolated during AprilJune 2009 (Fig. 2). These viruses were forced out by their genetically younger «relatives» allocated to clusters $1-3$.

The allocation of Ukrainian viruses to two different clusters confirms the imported character of influenza epidemics in Ukraine and effect of air travels on the speed of influenza spread.

When comparing HA amino acid sequences for $\mathrm{A}(\mathrm{H} 1 \mathrm{~N} 1) \mathrm{pdm}$ influenza viruses it was observed that the replacement of aspartic acid (D) for glycine (G) or glutamic acid (E) in 222 position, which the severity of disease is associated with, is typical forall viruses from 


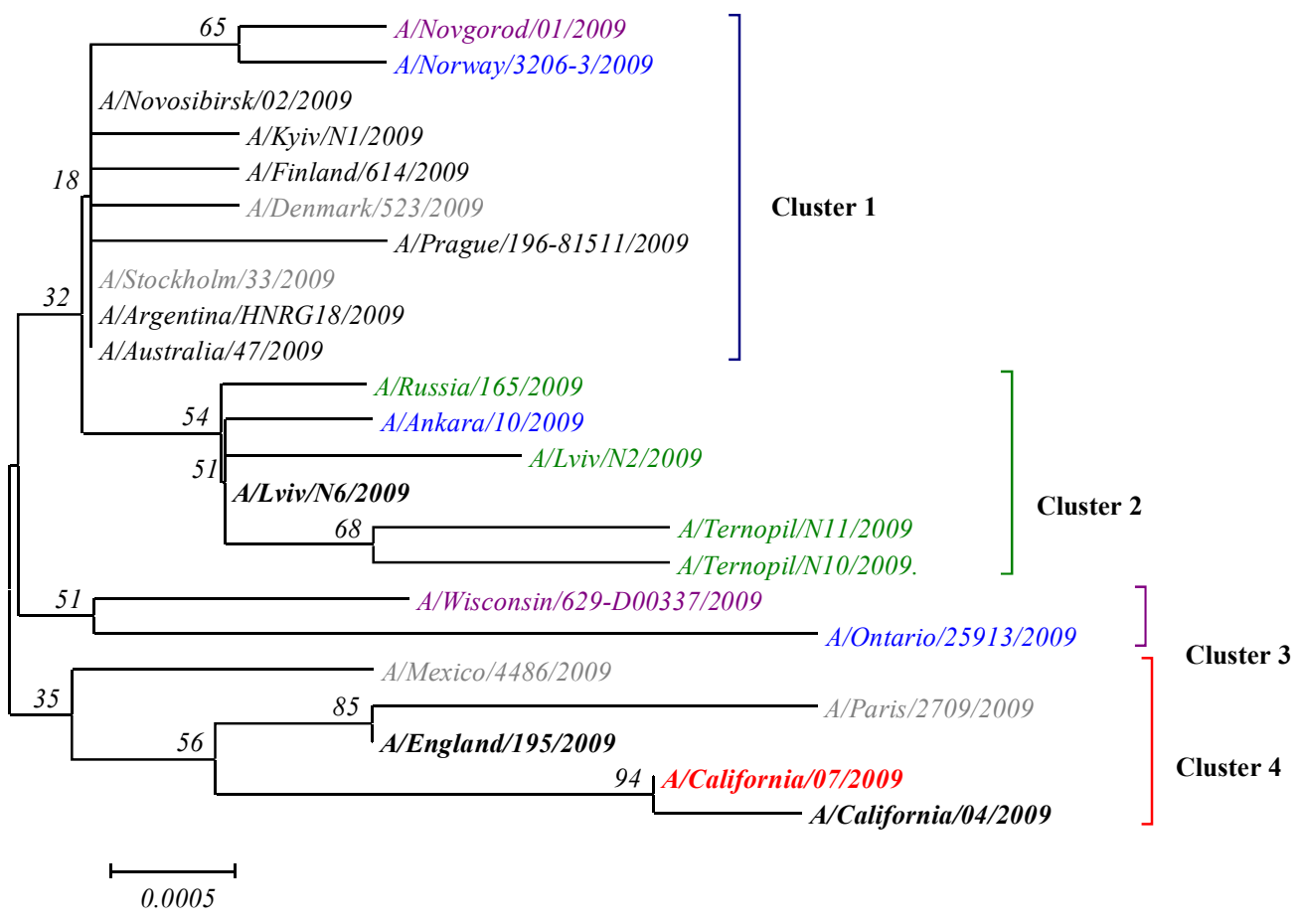

Fig. 2. Molecular phylogenetic analysis of HA nucleotide sequences for pandemic influenza viruses $\mathrm{A}(\mathrm{H} 1 \mathrm{~N} 1) \mathrm{pdm}$ the second cluster (among them Ukrainian ones: A/ Lviv/N2/2009, A/Lviv/N6/2009, A/Ternopil/N10/2009 and A/Ternopil/N11/2009), except A/Russia/165/2009 [17]. Aspartic acid was found in this position in $\mathrm{A} /$ Kyiv/N1/2009 isolate (cluster 1). In addition to the viruses allocated to the second cluster, only A/Novgorod/ $01 / 2009$ isolate from the cluster 1 had D222E mutation. We analyzed all cases of the disease complications for the patients from whom pandemic viruses were isolated. It was revealed that only isolates possessing D222G/E mutation (A/Norway/3206-3/2009, A/Lviv/ $\mathrm{N} 2 / 2009$ and $\mathrm{A} / \mathrm{Lviv} / \mathrm{N} 6 / 2009$ ) have led to lethal outcome of the disease. According to the literature sources this mutation facilitates virus replication in lower parts of respiratory tract by increasing the tropism to the corresponding host cell surface receptors $[17,18]$.

In addition, the S203T replacement is observed in HA amino acid sequence of all Ukrainian isolates and majority of $\mathrm{A}(\mathrm{H} 1 \mathrm{~N} 1) \mathrm{pdm}$ viruses as well. At the moment, this mutation is not associated with any structural or functional changes except for the site location on the surface of HA globule. The isolates allocated to clusters $1-3-i$. e. all viruses mutated from the oldest fourth cluster - had acquired this mutation. It is reasonable to suggest that this replacement turned out to be beneficial for pandemic influenza viruses.
The comparison of NA genes for pandemic isolates demonstrated that these genes are highly, $99 \%$, similar to each other. One may observe from the dendrogram (Fig. 3) that the specimen isolated from a swine in Beijing in $2008(\mathrm{~A} /$ swine/Beijing/21/2008) is located closest to pandemic influenza viruses [19]. The position of avian influenza viruses corresponds to the date of their sampling: A/duck/Eastern China/103/2003 virus is located close, while A/chicken/NY/21665-73/1998 virus - at a larger distance demonstrating smaller similarity.

The phylogenetic data presented in Fig. 3 confirm the results of previous study with respect to the origin of NA of pandemic influenza virus from that of avian influenza viruses [7]. All Ukrainian isolates of the 2009-2010 season belonged to pandemic influenza viruses (Fig. 3).

Similarly to $H A$ genes, the analysis of $N A$ genes was performed using only A/California/07/2009-like isolates. The results of comparison are given in Fig. 4 in the form of a phylogenetic tree. According to the differences in NA sequence, the pandemic viruses were allocated to three clusters. As compared with the results obtained for HA, the third cluster remained isolated while the first and second clusters experienced some regrouping (Fig. 2 and 4). A/California/07/2009 vaccine strain and A/California/04/2009 and A/England/ 

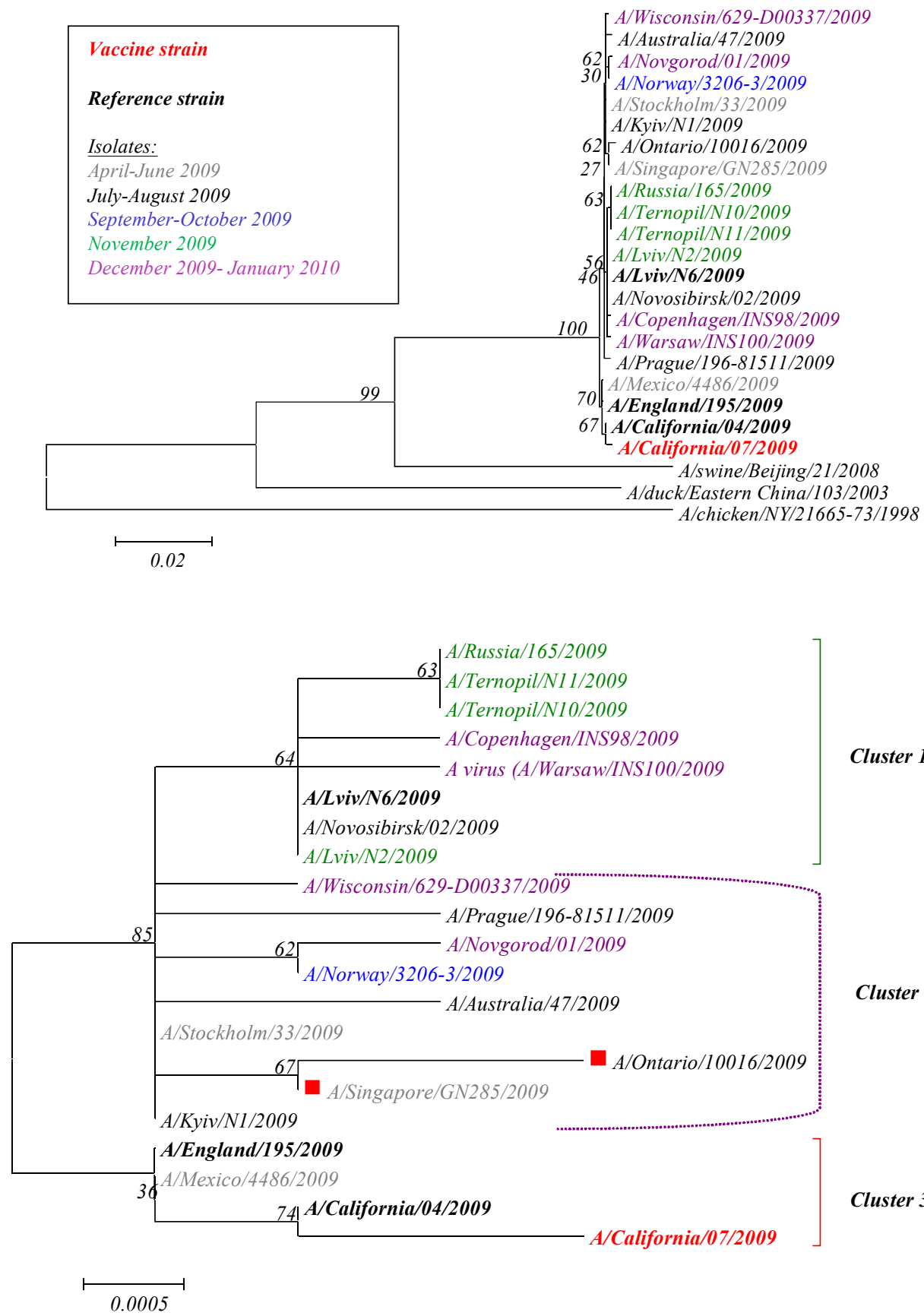

Fig. 3. Molecular phylogenetic analysis of NA nucleotide sequences for pandemic and seasonal influenza viruses $\mathrm{A}(\mathrm{H} 1 \mathrm{~N} 1)$
Cluster 1

Cluster 2

Cluster 3

$\mathrm{A} / \mathrm{Kyiv} / \mathrm{N} 1 / 2009$ isolate was allocated to the second cluster, together with the viruses isolated in summer of 2009 on the territory of other countries (Fig. 4). Thus, one may regard this as a confirmation that this virus and Ukrainian isolates allocated to the first cluster were imported to Ukraine by different ways.

NA sequences of isolates allocated to the first and second clusters contain a V106I replacement (valine is replaced by isoleucine) and N248D replacement (aspa2009 were within the first cluster (Fig. 4). 
ragine is replaced by aspartic acid). It is interesting that all isolates having V106I and N248D mutations in NA sequence possessed a S203T mutation in HA sequence as well.

During the last decade, the viruses resistant to the oseltamivir drug (Tamiflu) emerged, this is especially true for viruses of $\mathrm{A}(\mathrm{H} 1 \mathrm{~N} 1)$ subtype [20]. Due to the fact that the oseltamivir is a drug of choice when treating influenza, great attention is paid to the study of this resistance phenomenon. A specific $\mathrm{H} 275 \mathrm{Y}$ mutation was previously identified in NA gene according to which histidine is replaced by tyrosine. Some data indicate that this mutation is related to the development of oseltamivir resistance [21]. This mutation was identified in the Ukrainian isolates of 2007-2008 season as well (up to $35 \%$ ) [22]. The oseltamivir was a drug of choice in disease-specific therapy during the 20092010 influenza pandemic [23]. For this reason, the search for a $\mathrm{H} 275 \mathrm{Y}$ mutation in sequences of influenza viruses isolated in Ukraine allowed estimation of the sensitivity of the isolates to oseltamivir.

The analysis of NA sequences for pandemic influenza viruses isolated in Ukraine demonstrated that all isolates had histidine amino acid in position 275 and were oseltamivir-sensitive. Among the isolates originating from other countries only two, namely, A/Singapore/ GN285/2009 - from Singapore and A/Ontario/25913/ 2009 - from Canada, had a H275Y mutation within NA sequence (Fig. 4). They accounted for $9.5 \%$ (standard error of the mean $-13.28 \%$ ) of the total number of analyzed viruses. Our data confirm the results of other authors with respect to low levels of oseltamivir-resistant pandemic influenza viruses [24].

Conclusions. A high (99\%) genetic similarity of the Ukrainian isolates to the viruses isolated during pandemic in other countries provides an evidence of the stability of virus population during the first wave of the pandemic in Ukraine. The allocation of Ukrainian viruses to two different clusters points to different ways of their import to Ukraine.

The analysis of amino acid substitutions revealed the D222G/E and S203T mutations present in HA sequence of the majority of Ukrainian isolates. None of specimens isolated during the pandemic in Ukraine contained the $\mathrm{H} 275 \mathrm{Y}$ mutation in NA sequence which relates to the oseltamivir resistance.
Acknowledgements. We would like to thank Alexander I. Klimov (the Center for Disease Control and Prevention, USA) and Rod Daniels (World Influenza Centre, Great Britain) for help in performing sequencing of Ukrainian isolates.

\section{Л. В. Лейбенко, В. П. Поліщук, А. П. Міроненко}

Філогенетичний аналіз вірусів грипу А(H1N1)pdm, виділених в Україні протягом пандемічного сезону 2009-2010 років

Резюме

Мета. Здійснити філогенетичний аналіз сегментів, кодуючих гемаглютинін та нейрамінідазу пандемічних вірусів грипу A(H1N1) pdm, виділених в Україні. Методи. Полімеразно-ланцюгова реакиія у реальному часі (real-time RT-PCR), секвенування і філогенетичний аналіз. Результати. Проаналізовано ключові мутації в амінокислотних послідовностях поверхневих антигенів досліджуваних вірусів. Виявлено високу генетичну подібність (99\%) украӥнських ізолятів до вірусів, виділених в інших країнах. Висновки. Показано стабільність генів украӥнських ізолятів протягом пандемічного сезону 2009-2010 рр.

Ключові слова: філогенетичний аналіз, нуклеотидні послідовності, віруси грипу A(H1N1)pdm.

\section{Л. В. Лейбенко, В. П. Полищук, А. П. Мироненко}

Филогенетический анализ вирусов гриппа $\mathrm{A}(\mathrm{H} 1 \mathrm{~N} 1) \mathrm{pdm}$, выделенных в Украине в период пандемии 2009-2010 годов

Резюме

Цель. Осуществить филогенетический анализ сегментов, кодирующих гемагллютинин и нейраминидазу пандемических вирусов гриппа A(H1N1)pdm, выделенных в Украине. Методы. Полимеразная цепная реакиия в реальном времени (real-time RT-PCR), секвенирование и филогенетический анализ. Результаты. Проанализированы ключевые мутачии в аминокислотных последовательностях поверхностных антигенов исследуемых вирусов. Выявлено высокое генетическое сходство (99\%) украинского изолятов и вирусов, выделенных в других странах. Выводы. Показана стабильность генов украинских изолятов во время пандемического сезона 2009-2010 г2.

Ключевые слова: филогенетический анализ, нуклеотидные последовательности, вирусы гриппа A(H1N1)pdm.

\section{REFERENCES}

1. Gordon S. Avian influenza: a wake-up call from birds to humans // Cleve Clin. J. Med.-2004.-71, N 4.-P. 273-274.

2. Kaiser J. Public health. Pandemic or not, experts welcome Bush flu plan // Science.-2005.-310, N 5750.-P. 952-953.

3. Wan H., Sorrell E. M., Song H., Hossain M. J., Ramirez-Nieto G., Monne I., Stevens J., Cattolj G., Capua I., Chen L. M., Donis R. O., Busch J., Paulson J. C., Brockwell C., Webby R., Blanco J., Al-Natour M. Q., Perez D. R. Replication and transmission of H9N2 influenza viruses in ferrets: evaluation of pandemic potential // PLoS ONE.-2008.-3, N 8.-e2923.

4. Strategic advisory group of experts on immunization - report of the extraordinary meeting on the influenza A (H1N1) 2009 
pandemic (7 July 2009); Human infection with pandemic A (H1N1) 2009 influenza virus: clinical observations in hospitalized patients, Americas (July 2009 - update) // Weekly Epidemiological Record (WHO).-2009.-84, N 30.-P. 301-308.

5. Mironenko A. P., Onishchenko O. V., Golubka O. S., Kurinko N. A., Leibenko L. V. Pandemia of influenza in Ukraine in 20092010 winter season: lessons learned for future // Liky Ukrainy.2010.-N 10 (146).-P. 86-90.

6. Ma W., Lager K. M., Vincent A. L., Janke B. H., Gramer M. R., Richt J. A. The role of swine in the generation of novel influenza viruses // Zoonoses Public Health.-2009.-56, N 6-7.-P. 326-337.

7. Smith G. J., Vijaykrishna D., Bahl J., Lycett S. J., Worobey M., Pybus O. G., MaS. K., Cheung C. L., Raghwani J., Bhatt S., Peiris J. S., Guan Y., Rambaut A. Origins and evolutionary genomics of the 2009 swine-origin H1N1 influenza A epidemic // Nature.-2009.-459, N 7250.-P. 1122-1125.

8. Nava G. M., Attene-Ramos M. S., Ang J. K., Escorcia M. Origins of the new influenza A(H1N1) virus: time to take action // Eurosurveillance.-2009.-14, N 22.-pii: 19228.

9. McHardy A. C., Adams B. The role of genomics in tracking the evolution of influenza A virus // PLoS Pathog.-2009.-5, N 10.e1000566.

10. Tamura K., Peterson D., Peterson N., Stecher G., Nei M., Kumar $S$. MEGA5: molecular evolutionary genetics analysis using maximum likelihood, evolutionary distance, and maximum parsimony methods // Mol. Biol. Evol.-2011.-28, N 10.-P. 27312739.

11. Saitou N., Nei M. The neighbor-joining method: a new method for reconstructing phylogenetic trees // Mol. Biol. Evol.-1987.4, N 4.-P. 406-425.

12. Kimura $M$. A simple method for estimating evolutionary rate of base substitutions through comparative studies of nucleotide sequences // J. Mol. Evol.-1980.-16, N 2.-P. 111-120.

13. Felsenstein J. Confidence limits on phylogenies: An approach using the bootstrap // Evolution.-1985.-39, N 4.-P. 783-791.

14. Galiano M., Agapow P. M., Thompson C., Platt S. Underwood A., Ellis J., Myers R., Green J., Zambon M. Evolutionary pathways of the pandemic influenza A (H1N1) 2009 in the UK // PLoS One.-2011.-6, N 8.-e23779.

15. Danishuddin M., Khan S. N., Khan A. U. Phylogenetic analysis of surface proteins of novel H1N1 virus isolated from 2009 pandemic // Bioinformation.-2009.-4, N 2.-P. 94-97.
16. Han L., Lu W., Han Y., Li S., Yin J., Xie J., Su T., Cao G. Evolutionary characteristics of swine-origin H1N1 influenza virus that infected humans from sporadic to pandemic // J. Public Health and Epidemiol.-2011.-3, N 6.-P. 254-270.

17. Mak G. C., Au K. W, Tai L. S., Chuang K. C., Cheng K. C., Shiu T. C., Lim W. Association of D222G substitution in haemagglutinin of 2009 pandemic influenza A (H1N1) with severe disease // Euro. Surveill.-2010.-15, N 14.-pii 19534.

18. Puzelli S., Facchini M., Spagnolo D., De Marco M. A., Calzoletti L., Zanetti A., Fumagalli R., Tanzi M. L., Cassone A., Rezza G., Donatelli I., Surveillance Group for Pandemic A H1N1 2009 Influenza Virus in Italy. Transmission of hemagglutinin D222G mutant strain of pandemic (H1N1) 2009 virus // Emerg. Infect. Dis.-2010.-16, N 5.-P. 863-865.

19. Liu Y., Wang J., Ji J., Chang S., Xue C., Ma J., Bi Y., Xie Q. Phylogenetic diversity and genotypic complexity of H1N1 subtype swine influenza viruses isolated in Mainland China // Virol. J.-2012.-9.-P. 289.

20. Herlocher M. L., Truscon R., Elias S., Yen H. L., Roberts N. A., Ohmit S. E., Monto A. S. Influenza viruses resistant to the antiviral drug oseltamivir: transmission studies in ferrets // J. Infect. Dis.-2004.-190, N 9.-P. 1627-1630.

21. Lackenby A., Hungnes O., Dudman S. G., Meijer A., Paget W. J., Hay A. J., Zambon M. C. Emergence of resistance to oseltamivir among influenza A(H1N1) viruses in Europe // Euro. Surveill.2008.-13, N 5.-pii: 8026.

22. Leibenko L., Babii S., Kurinko N., Mironenko A. A four-year survey of the oseltamivir-resistant viruses in Ukraine $/ / 3^{\text {rd }}$ Int. Influenza Meet. (2-4 Sept. 2012, Munster, Germany).-Munster, 2012.-P. 108.

23. Updated interim recommendations for obstetric health care providers related to use of antiviral medications in the treatment and prevention of influenza for the 2009-2010 season (September 17, 2009).-Atlanta, 2009.

24. Leung T. W., Tai A. L., Cheng P. K., Kong M. S., Lim W. Detection of an oseltamivir-resistant pandemic influenza A/H1N1 virus in Hong Kong // J. Clin.Virol.-2009.-46, N 3.-P. 298-299.

Received 20.10.12 